\title{
Modelling vegetative growth, gamete production and encystment of dinoflagellates in batch culture
}

\author{
Louis Peperzak*
}

Rijksinstituut voor Kust en Zee (RIKZ), PO Box 8039, 4330 EA Middelburg, The Netherlands

Present address: Koninklijk Nederlands Instituut voor Onderzoek der Zee (NIOZ), PO Box 59, 1790 AB Den Burg, The Netherlands

\begin{abstract}
An intriguing case of encystment of the dinoflagellate Scrippsiella lachrymosa in culture has recently been presented: cyst concentrations still increased after the abundance of the vegetative cells had decreased to very low numbers. To account for this apparent time lag, and using a model with an encystment rate equation in which vegetative growth and encystment rates were coupled, the calculated growth and encystment rates had to be 8 to $12 \mathrm{~d}^{-1}$, values which were considered 'not biologically meaningful'. Here a new model of dinoflagellate growth and encystment is presented in which the mitotic cycle (vegetative growth) is coupled quantitatively to the sexual cycle (cyst formation) by having 4 gametes emanate from 1 vegetative cell, but without directly coupling the rates of vegetative growth and encystment. Calibrated on literature data of $S$. lachrymosa cultured in f/4 medium, this model satisfactorily describes motile cell (vegetative cells and gametes) and cyst development with correlations between log-transformed model and experimental data of $\mathrm{r}^{2}=0.80$ (motile cells) and $\mathrm{r}^{2}=0.94$ (cysts) and with typical maximum rates in the exponential growth phase of $\mu_{\text {cell }}=$ $0.55 \mathrm{~d}^{-1}$ (gross vegetative cell rate), $\mu_{\text {gamete+cell }}=0.38 \mathrm{~d}^{-1}$ (net motile cell growth rate), $\varepsilon=0.42 \mathrm{~d}^{-1}$ (encystment rate). All these rates declined in the stationary growth phase. Sample sonication is suggested as the cause for low motile cell concentrations in the original experiment when cyst production was high. Inorganic carbon limitation due to low inorganic carbon to nitrogen concentrations in the growth media is probably the reason why cysts in $\mathrm{f} / 4$ medium stopped making calcite covers in later stages of the experiment and why cyst yield in $\mathrm{f} / 2$ medium was not double the yield in $\mathrm{f} / 4$. A new method for measuring in situ encystment rates of dinoflagellate populations with a phased sexual cycle is proposed.
\end{abstract}

KEY WORDS: Dinoflagellate $\cdot$ Vegetative growth $\cdot$ Sexual cycle $\cdot$ Gametes $\cdot$ Cysts $\cdot$ Model

\section{INTRODUCTION}

The complex life cycle of many non-parasitic, autotrophic dinoflagellates contains haploid vegetative cells in the water column and diploid benthic resting stages called cysts or hypnozygotes (Fig. 1) (Dale 1983, Coats et al. 1984, Pfiester \& Anderson 1987, Pollingher 1988, Blackburn et al. 1989, Gao et al. 1989, Tomas et al. 1989, Giacobbe \& Yang 1999, Elbrächter 2003). Haploid vegetative dinoflagellate growth by binary fission is regulated in the mitotic cycle, which consists of 4 phases: Gap 1, Synthesis of DNA and Gap 2 + Mitosis (G1, S, G2M). Mitosis yields 2 haploid vegetative cells (Fig. 1). If the population is growing in phase, the growth rate can be modelled using the length of the
S- and or G2M-phases as so-called terminal events (McDuff \& Chisholm 1982, Carpenter \& Chang 1988). The sexual cycle starts when haploid vegetative cells produce gametes, but there is insufficient information on quantitative aspects of this process such as the number of gametes produced per cell and the proportion of the vegetative cell population forming gametes as well as the proportion of gametes that mate successfully (Lewis 2002). Furthermore, life cycle variations occur between species (Pollingher 1988, Elbrächter 2003). Generally, one vegetative cell is triggered into transforming into 4 gametes after 2 successive divisions (Coats et al. 1984, Tomas et al. 1989, Cetta \& Anderson 1990, Giacobbe \& Yang 1999), although in some cases 1 or 3 successive divisions lead to 2 or 8 


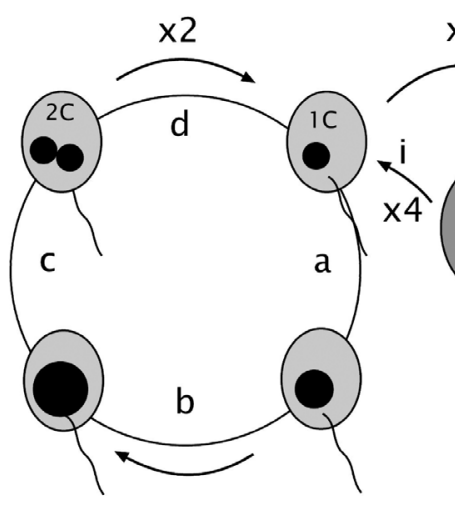

mitotic cycle

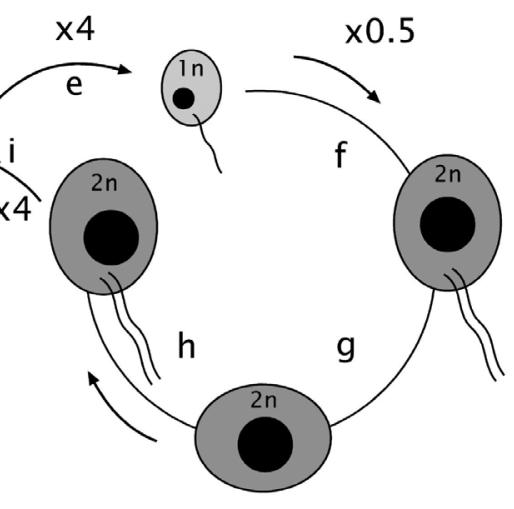

sexual cycle

Fig. 1. General scheme of mitotic and sexual cycle of a dinoflagellate. A haploid vegetative cell that is going to divide (a) synthesises a double amount of DNA (S-phase, (b) and after producing 2 nuclei (c) the cell divides (G2M-phase, d). The sexual cycle starts with a vegetative cell producing 4 haploid gametes via mitosis (e). Two gametes fuse to form a diploid planozygote (f), which encysts (g). After a mandatory resting period excystment takes place (h) and a diploid planomeiocyte emerges that produces 4 haploid vegetative cells after 2 consecutive meiotic divisions (i). $1 \mathrm{C}=$ nuclear DNA content in $\mathrm{G} 1,2 \mathrm{C}=$ double nuclear DNA content, $1 \mathrm{n}=$ haploid, $2 \mathrm{n}=$ diploid

gametes (von Stosch 1973, Pfiester 1975). Although gametes and vegetative cells may be morphologically similar in some species (Dale 1983, Blackburn et al. 1989, Gao et al. 1989, Elbrächter 2003, Figueroa \& Bravo 2005), the simple transformation of a haploid vegetative cell into a gamete has not yet been considered (Lewis 2002). Two gametes fuse to form a diploid planozygote, which has 2 longitudinal (trailing) flagella. The planozygote encysts, and, because the cyst has no flagella, it sinks to the bottom of the culture vessel or to the seafloor. After a mandatory rest period it can excyst and transform into a diploid planomeiocyte that, after 2 meiotic divisions, yields 4 vegetative cells. Fig. 1 shows a diagram of the combined, generalized, mitotic and sexual cycle of a dinoflagellate.

The factors that influence vegetative cell growth rate, the transitions between the different life cycle stages and the dynamics of encystment and excystment, i.e. the sexual cycle, are important in understanding dinoflagellate ecology. Recently a method was proposed to quantitatively describe the formation of cysts in terms of encystment probability and encystment rate (Olli et al. 2004). This method was based on observations that had been made in batch cultures of the dinoflagellate Scrippsiella lachrymosa Lewis in which a high encystment success was recorded (Olli 2002, Olli \& Anderson 2002). Basic to the method (Olli et al. 2004) were (1) the calculation of vegetative cell growth rates and encystment rates and (2) coupling of

these rates on the same temporal basis, which in effect led to maximum daily vegetative growth and encystment rates of 8 to $12 \mathrm{~d}^{-1}$, values that were considered 'not biologically meaningful'. The reliability of this method (Olli et al. 2004) is debatable. The direct coupling of growth and encystment rate appears not to be correct because gamete production, planozygote formation and encystment are separate processes, each of them having autonomous kinetics (Coats et al. 1984, Blackburn et al. 1989, Giacobbe \& Yang 1999).

Here a life cycle model of dinoflagellate growth and encystment is presented in which the mitotic cycle (vegetative growth) is coupled quantitatively to the sexual cycle (cyst formation) but without coupling directly the rates of vegetative growth, gamete production or cyst formation. This is a batch-culture-based model that allows the quantitative simulation of all life cycle stages. The model here will be tested on published Scrippsiella lachrymosa data in both $\mathrm{f} / 4$ and $\mathrm{f} / 2$ culture medium (Olli \& Anderson 2002, Olli et al. 2004).

\section{METHODS}

Life cycle scheme for dinoflagellates. Fig. 1 shows a life cycle scheme combining the vegetative cell growth (mitotic cycle) and the sexual cycle for dinoflagellates based on literature ccited in the 'Introduction'. With $\mathrm{n}=$ haploid and $2 \mathrm{n}=$ diploid the formula for an encysting vegetative cell according to this model is:

or:

$$
\begin{gathered}
1 \text { vegetative cell }(n)=4 \text { gametes }(n)= \\
2 \text { planozygotes }(2 n)=2 \text { cysts }(2 n)
\end{gathered}
$$

$$
1 \text { vegetative cell }(n)=2 \text { cysts }(2 n)
$$

The formation of 4 gametes by 2 asexual divisions has been observed for the dinoflagellates Gyrodinium uncatenum, Ceratium tripos, C. schrankii and Alexandrium taylori (Coats et al. 1984, Tomas et al. 1989, Cetta \& Anderson 1990, Giacobbe \& Yang 1999), and 2 arguments are presented here to justify the application of this process (Eq. 1a) in Scrippsiella lachrymosa. Firstly, the data from the f/4-medium experiment where nearly all cells encysted (Olli et al. 2004) make clear that the ultimate cyst concentration $\left(51.689 \mathrm{ml}^{-1}\right.$, when the cell concentration has become low), is close to twice (2.2) the maximum vegetative cell number on Day $16\left(23.186 \mathrm{ml}^{-1}\right)$, when the cyst concentration is still low. When accounting for the cysts already present on Day $16\left(8.118 \mathrm{ml}^{-1}\right)$, the cell:cyst ratio is $1: 1.9$. In other words, the cell:cyst ratio measured (Olli et al. 2004) is in accordance with the ratio 1:2 in the proposed life cycle (Fig. 1).

Secondly, particle-size measurements have shown that the small cell or gamete of Scrippsiella lachrymosa has a median spherical equivalent diameter (sed) of 
$12 \mu \mathrm{m}$ and the vegetative cell has a medium sed of $19 \mu \mathrm{m}$ (Olli 2002). In terms of volume the vegetative:gamete ratio is $3591 \mu \mathrm{m}: 904 \mu^{3}=4: 1$ and in accordance with the proposed life cycle (Fig. 1, Eq. 1). It is assumed here that large vegetative cells produce large cysts in the early stages of batch culture growth (Olli \& Anderson 2002) but that the smaller sized cysts in older cultures are due to limited resource availability, i.e. all cysts are produced from 2 gametes regardless of their size.

Calculation of rates and concentrations. In order to calculate all relevant rates and life cycle stage concentrations, a computer model was constructed that includes batch culture growth with 1 limiting nutrient (Fig. 2). The vegetative cell growth rate is calculated using a Monod-type equation. Although the N:P ratio of $\mathrm{f} / 4$ culture medium is 24 , the suggested N:P uptake ratio of Scrippsiella lachrymosa is 28 (Olli \& Anderson 2002), so that $\mathrm{NO}_{3}{ }^{-}$is the rate-determining nutrient:

$$
\mu_{t}=\left(\mu_{\max } \times\left[\mathrm{NO}_{3}{ }^{-}\right]_{t-1}\right) /\left(\mathrm{K}_{\mu, \mathrm{NO}_{3}}{ }^{-}+\left[\mathrm{NO}_{3}{ }^{-}\right]_{t-1}\right)
$$

$\mu_{t}$ is the growth rate $\left(\mathrm{d}^{-1}\right)$ at Day $=t, \mu_{\max }$ is the maximum growth rate $\left(\mathrm{d}^{-1}\right)$ under nitrate saturating conditions, $\left[\mathrm{NO}_{3}^{-}\right]_{t-1}$ is the nitrate concentration $\left(\mathrm{mol} \mathrm{m}^{-3}\right)$ at the end of the previous day (Day $=t-1$ ) and $\mathrm{K}_{\mu, \mathrm{NO}_{3}}{ }^{-}$ $\left(\mathrm{mol} \mathrm{m} \mathrm{m}^{-3}\right)$ is a constant: the nitrate concentration at which $\mu=0.5 \mu_{\max }$.

The nitrate concentration is calculated daily by subtracting the cumulative number of vegetative cells produced $(\Sigma)$ from the initial nitrate concentration (0.44 $\mathrm{mol} \mathrm{m}^{-3}$ in $\mathrm{f} / 4$ culture medium):

$$
\left[\mathrm{NO}_{3}^{-}\right]_{t}=\left[\mathrm{NO}_{3}^{-}\right]_{t=0}-\Sigma(\text { new cells })_{t} \times Q_{\mathrm{N}}
$$

where $\left[\mathrm{NO}_{3}{ }^{-}\right]_{t}$ and $\left[\mathrm{NO}_{3}{ }^{-}\right]_{t=0}$ are the nitrate concentration at Day $=0$ and Day $=t, \Sigma$ (new cells) ${ }_{t}$ is the cumulative amount of newly produced vegetative cells on Day $=t$ (total minus inoculum) and $Q_{\mathrm{N}}$ in mol cell ${ }^{-1}$ is the $\mathrm{N}$-quota for vegetative cells. The nitrogen quota is 9 pmol cyst $^{-1}$ (Olli \& Anderson 2002), and according to Eq. (1b) vegetative cells have $Q_{\mathrm{N}}=18 \mathrm{pmol} \mathrm{cell}{ }^{-1}$.

The growth rate $\mu_{t}$ from Eq. (2a) is used to calculate the concentration of vegetative cells at $t\left(\mathrm{Cell}_{t}\right)$ from the concentration of vegetative cells the previous day $\left(\mathrm{Cell}_{t-1}\right)$. The concentration of vegetative cells $\left(\mathrm{Cell}_{t-1}\right)$ has, however, declined during $24 \mathrm{~h}$ due to the formation of gametes (which are assumed not to grow). Therefore, Cell $_{t-1}$ has to be corrected by subtracting the vegetative cells that produced gametes:

$$
\text { Cell }_{t}=\left(\text { Cell }_{t-1}-\text { Cell }_{t-1} \times f_{\text {cell-gam }}\right) \times \mathrm{e}^{\mu}{ }_{t}
$$

where $f_{\text {cell-gam }}[0,1]$ is the fraction of vegetative cells producing gametes.

A problem is that the fraction of vegetative cells producing gametes, i.e. the rate of gamete production, is unknown. Because cysts, and therefore gametes, were produced throughout the Scrippsiella lachrymosa experiment (Olli \& Anderson 2002), it is assumed for practical reasons that the rate of gamete production $\left(f_{\text {cell-gam }}\right)$ was constant. However, the model can be extended to make the rate of gamete production dependent on the biomass limiting nutrient concentration or on vegetative cell concentration (Peperzak unpubl.).

The number of gametes on Day $=t$ is:

$$
\text { Gam }_{t}=\Sigma(\text { Cells })_{t-1} \times f_{\text {cell-gam }} \times r_{\text {cell-gam }}
$$

where $\mathrm{Gam}_{t}$ is the number of gametes $\left(\mathrm{m}^{-3}\right)$ produced at Day $=t, \Sigma(\text { Cells })_{t-1}$ is the cumulative amount of vegetative cells on the previous day and $r_{\text {cell-gam }}$ is the cell:gamete ratio, which is 4 (Eq. 1a).

The cumulative amount of gametes on Day $=t$ is:

$$
\Sigma(\operatorname{Gam} 1)_{t}=\Sigma(\mathrm{Gam})_{t-1}+\operatorname{Gam}_{t}
$$

A second problem is that the cumulative amount of gametes at Day $=t$ also has to be corrected because a number of them will have produced planozygotes and cysts. Because planozygotes were never observed in large numbers and encystment in Scrippsiella lachrymosa was always fast (<24 h) (Olli \& Anderson 2002), it will be assumed that cyst formation can be modelled as occurring instantaneously, i.e. planozygote formation (Fig. 1, Eq. 1a) is skipped and 2 gametes directly produce 1 cyst in the model. As with gamete production, the rate of cyst formation is not known a priori. It will be assumed that there is a constant fraction of gametes transforming into cysts, and, because cysts in the $S$. lachrymosa experiment were produced continuously (Olli \& Anderson 2002), the gamete-to-cyst fraction will also be assumed constant throughout the experiment.

The corrected cumulative amount of gametes on Day $=t$ is:

$$
\Sigma(\mathrm{Gam} 2)_{t}=\Sigma(\mathrm{Gam} 1)_{t}-\Sigma(\mathrm{Gam} 1)_{t} \times f_{\text {gam-cyst }}
$$

where $f_{\text {gam-cyst }}[0,1]$ is the fraction of gametes producing cysts.

The cyst production is:

$$
\text { Cyst }_{t}=\Sigma(\text { Gam } 1)_{t-1} \times f_{\text {gam-cyst }} \times r_{\text {gam-cyst }}
$$

where Cyst $_{t}$ is the number of cysts $\left(\mathrm{m}^{-3}\right)$ produced at Day $=t$ and $r_{\text {gam-cyst }}$ is the gamete:cyst ratio, which is 0.5 (Eq. 1a).

The cumulative amount of cysts on Day $=t$ is:

$$
\Sigma(\text { Cyst })_{t}=\Sigma(\text { Cyst })_{t-1}+\text { Cyst }_{t}
$$

Because the data of the Scrippsiella lachrymosa experiment are provided as cyst and 'motile cell' concentrations (Olli et al. 2004), the model calculates an extra variable, the sum of vegetative cells and gametes:

$$
\text { Motile cell }=\text { Cell }_{t}+\text { Gam }_{t}
$$




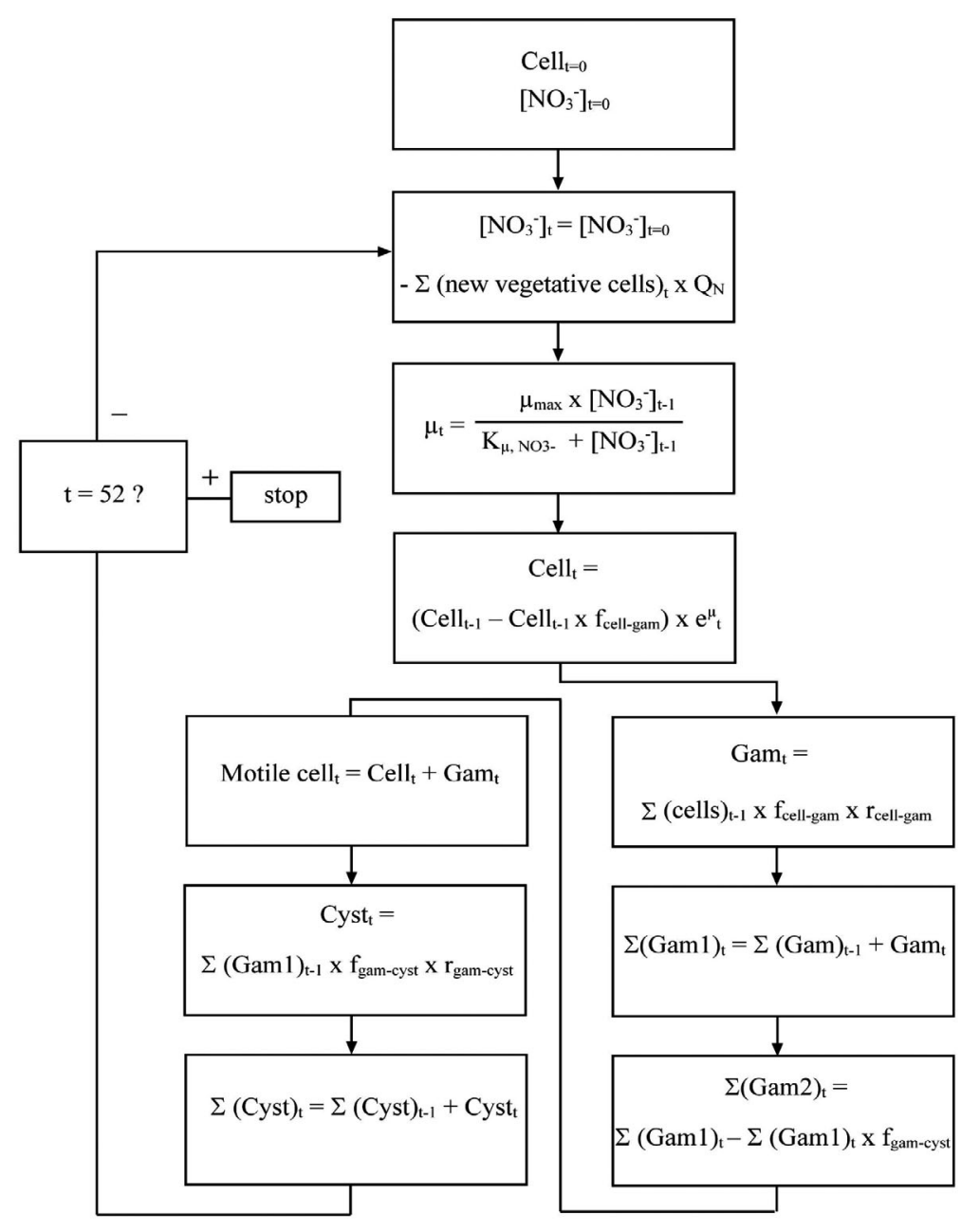

Fig. 2. Model scheme for dinoflagellate growth, gamete production and encystment in batch culture. New vegetative cells are produced as long as nitrate is available (steps a-d in Fig. 1). Gametes are produced (step e, Fig. 1) as a constant daily fraction of vegetative cells $\left(f_{\text {cell-gam }}\right)$, and cysts are produced as a constant daily fraction of gametes $\left(f_{\text {gam-cyst }}\right)$. See Eqs. $(2 \mathrm{a}-g)$. The planozygote lifetime in Scrippsiella lachrymosa is so short that cyst formation is assumed to occur instantaneously (steps $\mathrm{f}+\mathrm{g}$, Fig. 1). In simulating $S$. lachrymosa encystment the vegetative cell:gamete ratio $\left(r_{\text {cell-gam }}\right)$ was varied; the gamete:cyst ratio $\left(r_{\text {gam-cyst }}\right)$ was 0.5

Model calculations. The data used to calibrate the model (Fig. 2) are the motile cell and cyst concentrations in an f/4 culture medium experiment in which 24 test tubes with $10 \mathrm{ml}$ culture medium each was inoculated with exponentially growing Scrippsiella lachrymosa cells and incubated for a maximum of $52 \mathrm{~d}$ (Olli et al. 2004). Counts were made 8 times after simultaneously sacrificing 3 tubes, first at 4 d intervals but later at longer intervals. The tubes were probe sonicated for a few seconds to agitate the cysts that had settled to the bottom, and the samples were preserved with Utermöhl solution. Full details can be found in Olli \& Anderson (2002). The outcome of a comparable exper- iment in f/2 culture medium (Olli et al. 2004) was used to validate the model.

The calculations (Eqs. $2 \mathrm{a}-\mathrm{g}$ ) were made with time steps of $1 \mathrm{~d}$ in a spreadsheet program (Excel) allowing direct computational and graphical evaluation of model outcome against experimental data. Model input variables (Table 1) were changed to optimise the linear correlation coefficients between model output and experimental data of log-transformed motile cell and cyst concentrations respectively.

The model was first tested by changing the input variables $\mu_{\max }$ and $\mathrm{K}_{\mu, \mathrm{NO}_{3}}$ (Table 1 ). If experimental growth rates from Day 0 to Day 12 in both f/4 and f/2 medium are averaged, a lower $\mu_{\max }=0.47 \mathrm{~d}^{-1}$ is obtained (Olli et al. 2004). $\mathrm{K}_{\mu_{1} \mathrm{NO}_{3}}$ is unknown, and therefore a value one third the $\mathrm{K}_{\mathrm{s}, \mathrm{NO}_{3}}$ of Peridinium cinctum was used (Pollingher 1988). Secondly, the cellgamete $\left(f_{\text {cell-gam }}\right)$ fraction was varied. Thirdly, the number of gametes produced by a vegetative cell ( $\left.\mathrm{r}_{\text {cell-gam }}\right)$ was reduced from 4 (Eq. 1a) to 1 (a cell behaving functionally as a gamete). Because a reduction in $\mathrm{r}_{\text {cell-gam }}$ changes the ratio of vegetative cells:cysts (Eq. 1b), the Nquota has to be changed accordingly as:

$$
\begin{gathered}
1 \text { cell }=4 \text { gametes }=2 \text { cysts }(=2 \times 9 \text { pmol } \mathrm{N}) \\
\Rightarrow 1 \text { cell }=18 \text { pmol } \mathrm{N} \\
2 \text { cells }=2 \text { gametes }=1 \text { cyst }(=9 \text { pmol } \mathrm{N}) \\
\Rightarrow 1 \text { cell }=4.5 \text { pmol } \mathrm{N}
\end{gathered}
$$

This means a reduction of $Q_{\mathrm{N}}=18\left(r_{\text {cell-gam }}=\right.$ $4)$ to $Q_{\mathrm{N}}=4.5\left(r_{\text {cell-gam }}=1\right)$. The gamete:cyst ratio ( $\left.r_{\text {gam-cyst }}\right)$ was kept constant at 0.5 in all calculations because the only feasible way to form a diploid cyst is by fusion of 2 haploid gametes (Fig. 1).

The encystment percentage $(\mathrm{E} \%)$ is calculated from the ratio of the cumulative concentrations of vegetative cells and cysts:

$$
\mathrm{E} \%=100 \times \Sigma(\text { Cyst })_{t=52} / \Sigma(\text { vegetative cells })_{t=52}
$$

\section{RESULTS}

The results or model output, obtained by changing the input variables of the model (Table 1), are shown in Table 2. In each run, one input variable was changed to observe the effect on the timing and maximum concentrations of motile cells and cysts and the correlation between the modelled values and those observed experimentally (Olli et al. 2004). A reduction of $\mu_{\max }$ from 0.56 to $0.47 \mathrm{~d}^{-1}$ (run 2) and an increase of $K_{\mu}$ from 0.01 to 0.03 (run 3 and 4 ) resulted in lower correlation 
Table 1. Input variables for run 1 of model calibration of Scrippsiella lachrymosa growth, gamete formation and cyst production in $\mathrm{f} / 4$ culture medium

\begin{tabular}{|c|c|c|c|}
\hline Variable & & Value & Source/Reference \\
\hline Nitrate at $t=0$ & {$\left[\mathrm{NO}_{3}\right]_{t=0}$} & $0.442 \mathrm{~mol} \mathrm{~m}^{-3}$ & Olli \& Anderson (2002) \\
\hline Maximum growth rate & $\mu_{\max }$ & $0.56 \mathrm{~d}^{-1}$ & $\begin{array}{l}\text { Calculated for Days } 0-8(n=3) r^{2}=0.96 \text {, } \\
\text { Table } 1 \text { (Olli et al. 2004) }\end{array}$ \\
\hline Half saturation constant for growth & $K_{\mu, \mathrm{NO}_{3}}$ & $0.01 \mathrm{~mol} \mathrm{~m}^{-3}$ & $\begin{array}{l}1 / 3 \text { of } K_{\mathrm{s}, \mathrm{NO}_{3}} \text { Peridinium cinctum } \\
\text { (Pollingher 1988) }\end{array}$ \\
\hline N quota & $Q_{\mathrm{N}}$ & 18 pmol $\mathrm{N} \mathrm{cell}^{-1}$ & 9 pmol N cyst ${ }^{-1}$ (Olli \& Anderson 2002) \\
\hline Cells at $t=0$ & Cell $_{t=0}$ & $1 \times 10^{8} \mathrm{~m}^{-3}$ & Olli et al. (2004) \\
\hline Daily fraction of vegetative cells producing gametes & $f_{\text {cell-gam }}$ & 0.1 & Range: $0-1$ \\
\hline Vegetative cell:gamete ratio & $r_{\text {cell-gam }}$ & 4 & See 'Methods' \\
\hline Daily fraction of gametes producing cysts & $f_{\text {gam-cyst }}$ & 0.5 & Range: $0-1$ \\
\hline Gamete to cyst ratio & $r_{\text {gam-cyst }}$ & 0.5 & See 'Methods' \\
\hline
\end{tabular}

coefficients, and therefore the following runs were made with $\mu_{\max }=0.56$ and $K_{\mu}=0.01$. Changing the daily fraction of vegetative cells that produced gametes from 0.0 to 0.4 (runs 5 to 11 ) led to a modelled cyst concentration ranging from 0 to $1.3 \times 10^{10}$ with a maximum of $4.9 \times 10^{10}$ cysts $\mathrm{m}^{-3}$ reached at $f_{\text {cell-gam }}=$ 0.15 (run 8 ). The maximum motile cell and cyst concentrations in the experiment were $2.3 \times 10^{10} \mathrm{~m}^{-3}$ and $5.2 \times$ $10^{10} \mathrm{~m}^{-3}$ (Olli et al. 2004); $105 \%$ and $95 \%$ of these numbers were reached in run 8 . Therefore, $f_{\text {cell-gam }}=0.15$ was used in ensuing calculations.

Changing the daily fraction of gametes that produced cysts from 0.0 to 1.0 (runs 12 to 16) led to a combined correlation coefficient ranging from 0.01 to $1.73-1.74$; the maxima were reached at $f_{\text {gam-cyst }}=$ 0.75-1.0 (runs 15 and 16). The calculated maximum motile cell concentration decreased from $9.8 \times 10^{10} \mathrm{~m}^{-3}$ (426\%, Day 48, run 12) to $1.7 \times 10^{10} \mathrm{~m}^{-3}$ (74\%, Day 14 , run 16). The maximum cyst concentration in the experiment was $5.2 \times 10^{10} \mathrm{~m}^{-3}$ on Day $52 ; 4.9 \times 10^{10}$ cysts m $^{-3}$ on Day 51 (94\%) were calculated in runs 15 and 16 . Run 16 had the highest correlation coefficients between calculated and measured motile cell and cyst concentrations $\left(r^{2}=0.80\right.$ and $\left.r^{2}=0.94\right)$ (Fig. 3). In run 16 nitrate became depleted on Day 14; at that time $25 \%$ of the total cyst yield had already been produced.

Next, the ratio of vegetative cells producing gametes $\left(r_{\text {cell-gam }}\right)$ was reduced from 4 to 1 in runs 17 and 18 with the other input variables as in run $8\left(f_{\text {gam-cyst }}=0.5\right)$ and run $16\left(f_{\text {gam-cyst }}=1.0\right)$ and with $\mathrm{N}$ quota at $25 \%$ (Eq. $\left.2 \mathrm{~h} 2\right)$. This led to spurious maximum motile cell concentrations in both runs 17 and 18 of more then $3 \times$ the concentrations measured in the experiment (Fig. 4, Table 2). On the other hand, the calculated maximum cyst correlation was still $94 \%$ of measured values (Table 2 ).

As expected, rerunning the model for run 16 with $\mathrm{f} / 2$ instead of $\mathrm{f} / 4$ nitrate concentrations in run 19 doubled both motile cell and cyst maximum concentrations to
$3.7 \times 10^{10} \mathrm{~m}^{-3}$ and $9.8 \times 10^{10} \mathrm{~m}^{-3}$ (Table 2). However, in contrast to expectations, the measured cyst yield in $\mathrm{f} / 2$ was lower than in f/4 medium (Olli et al. 2004). Although the model accurately calculated the maximum motile cell concentration $(100 \%)$, the maximum concentration of the cysts appeared to be overestimated (272\%, Table 2).
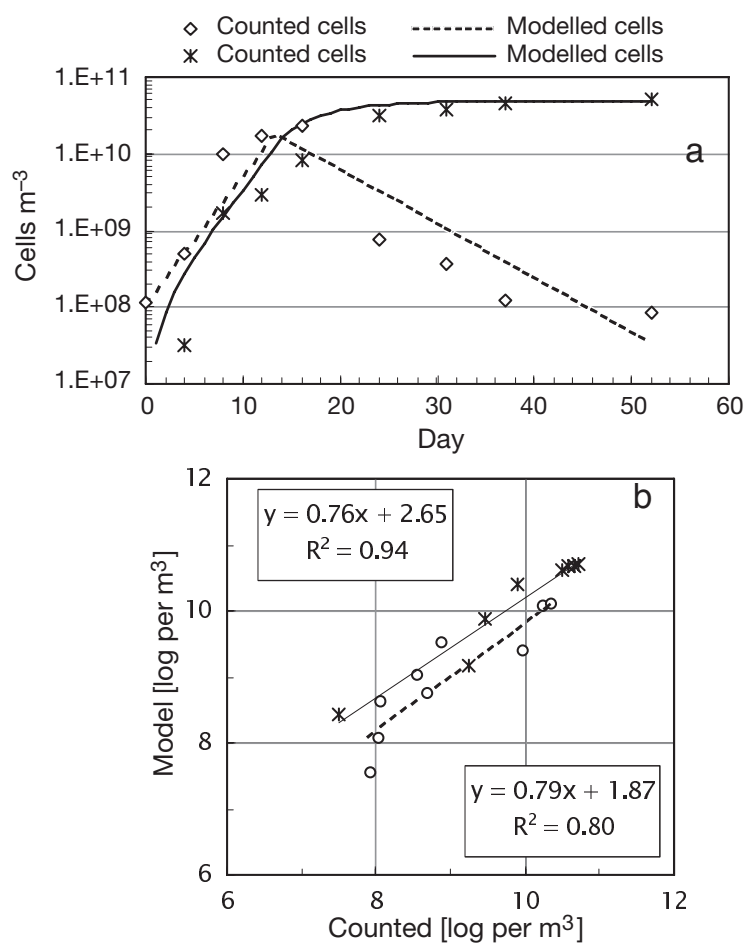

Fig. 3. Scrippsiella lachrymosa. Model results for run 16 : (a) development of motile cell (vegetative cell and gamete) and cyst concentrations in $\mathrm{f} / 4$ batch culture growth. Symbols $=$ measured values, lines $=$ model results. According to the model, nitrate became depleted on Day 14 (not shown); (b) linear regression of modelled concentrations over experimental data (cells $\mathrm{r}^{2}=0.80$, cysts $\mathrm{r}^{2}=0.94$ ) 


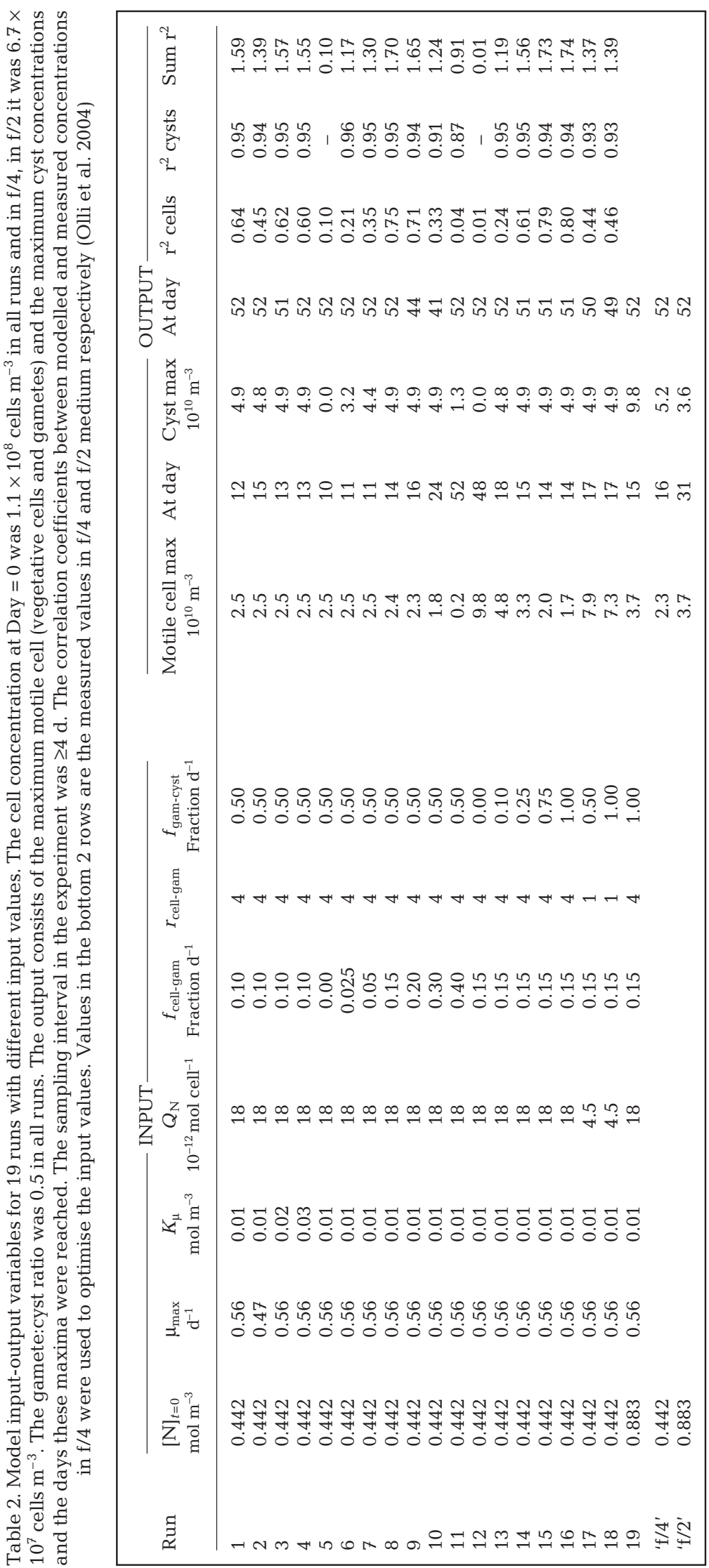

Typical rates of vegetative cell and 'motile cell' growth, and encystment in exponential and stationary growth phase for run 16 (Fig. 3) are shown in Table 3. The encystment percentage $(\mathrm{E} \%)$ in run 16 was $100.1 \%$.

\section{DISCUSSION}

The new model to calculate the growth and encystment of Scrippsiella lachrymosa in batch culture (Fig. 2) gives adequate quantitative results (Fig. 3, Table 2) despite the 'poor counting statistics' (Olli et al. 2004) and a number of assumptions that had to be made (Table 1). To calculate vegetative cell growth, a maximum growth rate had to be estimated from experimental 'motile cell' counts. The growth rate $\mu$ in Olli et al. (2004) is in fact not a vegetative cell growth rate but a 'motile cell' rate calculated from the rate of change in the combined vegetative cell and gamete concentrations (Olli \& Anderson 2002). The maximum growth rate used in the model ( $\mu_{\max }$, Table 1$)$ was calculated from the first 3 available 'motile cell' counts (Olli et al. 2004), assuming that gamete concentrations then were still low and negligible. A lower growth rate $(\mu=$ $0.47 \mathrm{~d}^{-1}$ ) calculated from both the $\mathrm{f} / 4$ and $\mathrm{f} / 2$ experiments did not improve model output (Table 2, run 2). The difference between the modelled gross vegetative and the net 'motile cell' growth rates was $0.17 \mathrm{~d}^{-1}(-31 \%$, Table 3$)$. Therefore, in future quantitative studies of the sexual cycle of dinoflagellates, vegetative cells and gametes should preferably be counted separately, not together as 'motile cells'. Because vegetative cells and gametes may be difficult to discern, there is a need for molecular tools that enable rapid identification and enumeration of dinoflagellate life cycle stages (Garces et al. 2002). The application of molecular tools can also lead to fulfil the much desired wish to increase the number of quantitatively described dinoflagellate life cycles (Lewis 2002).

The half saturation constant $K_{\mu, \mathrm{NO}_{3}}{ }^{-}$ which is needed to calculate vegetative cell growth rate between exponential and stationary growth phase, i.e. under 


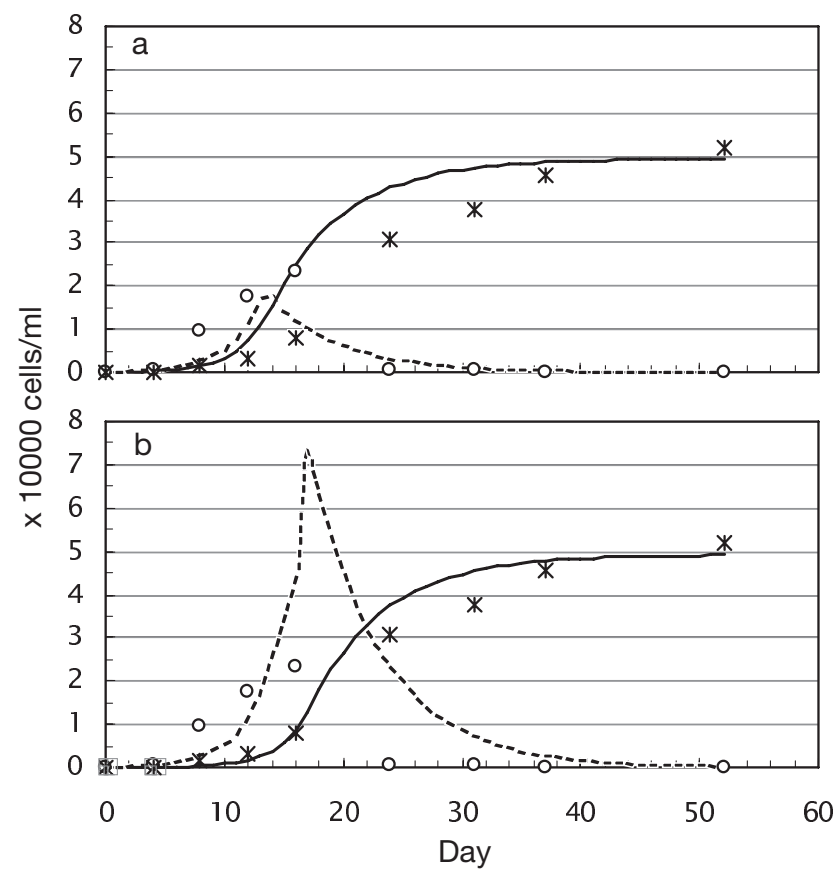

Fig. 4. Scrippsiella lachrymosa model results for run 16 (a) with one vegetative cell of $S$. lachrymosa producing 4 gametes and run 18 (b) with one vegetative cell producing one gamete. Note the vertical axis, which has the same (linear) dimensions as in the original publication (Olli et al. 2004). Symbols $=$ measured values, lines $=$ model results

Table 3. Typical rates on Day 7 and Day 21 (exponential and stationary growth phase) in run 16 (see Fig. 4). Motile cells are vegetative cells and gametes

\begin{tabular}{|lccc|}
\hline \multicolumn{2}{|c|}{$\begin{array}{c}\text { Gross vegetative } \\
\text { cell growth rate, } \mathrm{d}^{-1}\end{array}$} & $\begin{array}{c}\text { Net motile cell } \\
\text { growth rate, } \mathrm{d}^{-1}\end{array}$ & $\begin{array}{c}\text { Encystment } \\
\text { rate, } \mathrm{d}^{-1}\end{array}$ \\
\hline Exponential & 0.55 & 0.38 & 0.42 \\
Stationary & 0.00 & -0.16 & 0.05 \\
\hline
\end{tabular}

nitrate-limiting conditions (Eq. 2a, Table 1), had to be derived from a different constant, $K_{\mathrm{s}_{1} \mathrm{NO}_{3}}{ }^{-}$, of a different species. However, changing $K_{\mu_{1} \mathrm{NO}_{3}}{ }^{-}$did not have large effects on maximum cell and cyst concentrations (Table 2, runs 1 to 4 ). There are 2 reasons for this. Firstly, the transition period between exponential and stationary growth in the model was very short (ca. 1 d). Secondly, cell and cyst concentrations are largely determined by the initial nitrate concentration and $\mathrm{Q}_{\mathrm{N}}$, the N-quota for cells and cysts. $K_{\mu}$ is more important in modelling species with lower growth rates and can then be used to fine-tune the vegetative cell growth rate in the exponential-stationary phase transition period.

The ratios of cell-gamete and gamete-cyst production $\left(r_{\text {cell-gam }}=4\right.$ and $r_{\text {gam-cyst }}=0.5$ respectively) were derived from several sources in the literature (Fig. 1 and references in the introduction). A gamete:cyst ratio of 0.5 is generally believed to be correct (Olli \& Anderson 2002) because the plausible way in which the diploid cyst is produced is from 2 fusing haploid gametes with the diploid planozygote as intermediate.

There are 3 arguments for why a cell:gamete ratio of 4 is appropriate in the case of Scrippsiella lachrymosa. First, it was calculated on the basis of the approximate vegetative cell:cyst ratio $(2: 1)$ in the $f / 4$ experiment (Olli et al. 2004). Second, the volume of 4 gametes equals that of 1 vegetative cell (Olli 2002). A similar volume ratio has been found in the sexual cycle of Gyrodinium uncatenum between predivision vegetative cells and gametes (Coats et al. 1984) and between micro- and mesoflagellates-presumed gametesand diploid non-flagellated cells in the life cycle of the prymnesiophyte Phaeocystis globosa (Peperzak et al. 2000). However, this volume argument is not decisive: vegetative cell:gamete volumes in dinoflagellates may range from a factor of 2 to 5 (Coats et al. 1984, Pollingher 1988). Third, the choice of $r_{\text {cell-gam }}=4$ led to calculated maximum motile (vegetative + gamete) cell concentrations comparable to the counts in $\mathrm{f} / 4$ medium (Table 2, runs 1 to 9). The alternative, reducing $r_{\text {cell-gam }}$ from 4 to 1 , tripled the calculated maximum motile cell concentrations (runs 17 to 18, Table 2, Fig. 4b). At first, this appears contradictory because when vegetative cells produce fewer gametes, fewer motile cells are expected. However, according to Eqs. (2h1) \& (2h2), the cell-cyst stoichiometry has to change too. Because a cyst contains 9 pmol N (Olli \& Anderson 2002) and a diploid cyst is formed from 2 haploid gametes, each containing $4.5 \mathrm{pmol} \mathrm{N}$, a vegetative cell also has a $Q_{\mathrm{N}}=$ $4.5 \mathrm{pmol} \mathrm{N}$ if one gamete emanates from one vegetative cell. In effect, the decrease in cell $Q_{\mathrm{N}}$ from 18 to 4.5 pmol $\mathrm{N}$ means that from the initial nitrate concentration $\left(0.442 \mathrm{~mol} \mathrm{~m}^{-3}\right) 4$ times as much vegetative cells can be produced.

As shown in Fig. 4b, the assumption of 1 cell producing only one gamete leads to motile cell concentrations from day 12 onwards that appear spuriously high compared to measured, as well as to modelled motile cell concentrations using $r_{\text {cell-gam }}=4$ (Fig. $4 \mathrm{a}$ ). Modelling the encystment of other dinoflagellate species with little or no morphological differences between vegetative cells and gametes, or with gametes that have a very short lifetime, will provide an additional, numerical method of investigating if the cell:gamete ratio of 4 is appropriate in those species too.

The optimum daily fraction of vegetative cells producing gametes $\left(f_{\text {cell-gam }}=0.15\right.$, run 8 , Table 2$)$ is a value intermediate to no gamete production $\left(f_{\text {cell-gam }}=\right.$ 0.0 , run 5, Table 2) and a gamete production rate that nearly equals the growth rate of the vegetative cells $\left(f_{\text {cell-gam }}=0.4\right.$, run 11 , Table 2$)$. In the first case, no cysts 
are produced. In the latter case, gametes are produced so quickly that vegetative cells have no time to enter the mitotic cycle and divide by binary fission (Fig. 1). In other words, the rate of gamete production then severely limits vegetative growth rate so that insufficient new vegetative cells, and hence gametes and cysts, are produced. This is reflected in the model output first as a breakdown of the correlation coefficient between observed and modelled motile cell concentrations and, second, by low cyst concentrations (Table 2, run 11). In batch cultures with encysting dinoflagellates, $f_{\text {cell-gam }}$ is in fact the loss factor that reduces gross vegetative cell growth rate to a net growth rate. If, however, the encystment rate is taken as the direct loss factor (Olli et al. 2004), the intermediate gamete stage with its own kinetics (Fig. 2) is incorrectly omitted from population dynamics.

In the stationary growth phase, any increase in cyst concentration and encystment rate at low vegetative cell concentrations (Olli et al. 2004) must then be accounted for by an equivalently high growth rate, which is unrealistic because nutrients have been depleted. In the present model (Fig. 2), vegetative cells constantly form a 'reservoir' of gametes that continuously produces cysts, even after Day 14 when nitrate has been depleted (Fig. 3, Table 3). This means that cyst production can continue without the need for vegetative cell growth, as apparently was the case in the Scrippsiella lachrymosa f/4 batch culture.

The coupling of encystment rate with growth rate is probably not the only cause of the extremely high values $\left(>8 \mathrm{~d}^{-1}\right)$ of the calculated growth rates in the equation by Olli et al. (2004). Low motile cell counts in the stationary growth phase may have been caused by the probe sonication that was applied to agitate the cysts that had settled to the bottom of the culture tubes. Using an ultrasonic cleaning bath, mild 1 min sonication of natural samples containing vegetative cells and gametes of Scrippsiella trochoidea destroyed $10 \%$ of the vegetative cells and $30 \%$ of the gametes (Peperzak unpubl. data). Furthermore, a longer probe sonication of $1 \mathrm{~min}$ has been used purposely to destroy motile cells in cyst-containing Alexandrium tamarense cultures (Anderson et al. 1984). Therefore, it is likely that probe sonication in the $S$. lachrymosa samples destroyed a considerable number of motile cells, thereby lowering the cell counts and hence, in order to numerically compensate for this loss, leading to an overestimation of growth rates.

The final step in the encystment process, the formation of cysts from gametes, could be modelled optimally at values of $f_{\text {gam-cyst }}=0.75$ to 1.0 (Table 2 , runs 8 and 16). Such a high daily fraction of gametes that produces cysts also means that the intermediate stage, the planozygote, has a short life span $(<1 \mathrm{~d})$. This is in accordance with the low numbers of Scrippsiella lachrymosa planozygotes that were observed in the experiment and corroborates the suggestion that this stage has a short duration (Olli 2002). In addition, apparently no observations of fusing gametes were made in the experiment. This may be due to the altogether rapid transformation of gametes into cysts, but it may also be emphasized by the possibility that gamete fusion only takes place during a certain, relatively short, period in the diel cycle (Pfiester 1975, Coats et al. 1984) that is not sampled.

The model, which assumes constant gamete and cyst formation (Fig. 2), can be extended to account for the timing of cyst formation that appears to be several days early compared to measured cyst concentrations (Figs. 3a \& 4a). Such an extension could be based on the perception that gametes are formed below a certain nutrient concentration (Anderson et al. 1984) or above a threshold vegetative cell concentration (Peperzak unpubl.) or that encystment simply begins at the peak of exponential growth (Dale 1983). Experiments at ecologically relevant nutrient concentrations and cell abundances are needed to determine the mechanisms that induce gamete formation, gamete fusion and transformation of the planozygote into a cyst. In addition, modelling of the dinoflagellate sexual cycle may prove more difficult than in Scrippsiella lachrymosa if encystment is regulated by a complex interplay of nutrient concentration with several other factors such as day length and temperature (Sgrosso et al. 2001). Furthermore, several dinoflagellate species are capable of forming asexual resting spores (hypnospores) which are very similar to hypnozygotes (van den Hoek et al. 1995). Because hypnospores are haploid, the present model for hypnozygotes will probably not function appropriately and should be adapted.

If indeed gamete fusion and planozygote and cyst formation take place during defined time windows in the sexual cycle (Coats et al. 1984), the possibility of measuring the encystment rate becomes possible, even in the sea (in situ) and without bottle incubations. In the mitotic cycle (Fig. 1) the specific fraction of the population that is going to divide increases its DNA content during S-phase and has a double DNA content in the G2M phase. The duration of both phases can be used as terminal events, key variables that form the basis of modelling in situ vegetative growth rates (McDuff \& Chisholm 1982, Carpenter \& Chang 1988, Chang \& Carpenter 1988). Likewise, a phased transition in the sexual cycle, haploid gametes forming diploid planozygotes and planozygotes forming cysts, provides a possibility of measuring in situ encystment rates. This means identification of individual cells, quantification of their DNA content, enumeration of the different stages and use of the duration of the 
planozygote stage as a terminal event. Besides a phased transition, another condition would be that all diploid stages, fusing gametes, the planozygote, the cyst and the vegetative cell in G2M phase must be readily distinguishable from each other. Besides differences in pigmentation and the extra 'trailing flagellum', planozygotes are 1 to 2 times larger in size than vegetative cells, and gametes are 1 to 2 times smaller in size than vegetative cells (Coats et al. 1984, Blackburn et al. 1989, Giacobbe \& Yang 1999). However, in several species such differences in length or width may not exist or are difficult to measure and to use in the identification of the sexual stages. Furthermore, there may be large intraspecific ranges in each stage's size (Coats et al. 1984). In such cases there is a need for specific molecular probes that label, for instance fluorescently, the different stages in the vegetative and sexual cycles (Garces et al. 2002). Cysts are morphologically very distinct from motile cells (Dale 1983), and their formation may be used to define the end of the planozygote terminal event. Although the measurement of the in situ encystment rate appears to be a challenging task, because encystment is a key step in dinoflagellate ecology the feasibility of the technique deserves further study.

After testing the model input variables (Table 1, Fig. 2) that were inherent to the Scrippsiella lachrymosa vegetative and sexual cycles and comparing the output with the experimental results in f/4 medium (Table 2), the model was validated on data obtained in $\mathrm{f} / 2$, a medium with added nutrient concentrations double that of $\mathrm{f} / 4$ (Olli \& Anderson 2002). Unfortunately, the measured cyst yield in $f / 2$ was lower than in $f / 4$ (Olli et al. 2004). The model correctly predicted motile cell concentrations in $\mathrm{f} / 2\left(3.7 \times 10^{10} \mathrm{~m}^{-3}\right)$ and a final cyst concentration twice that in $\mathrm{f} / 4\left(9.8 \times 10^{10} \mathrm{~m}^{-3}\right.$, Table 2, run 19). In fact, the model accurately calculated the cyst yield $\left(10^{11} \mathrm{~m}^{-3}\right)$ of Scrippsiella lachrymosa in f/2 medium when grown in culture plate wells (Olli \& Anderson 2002) instead of culture tubes (Olli et al. 2004).

Coupled with the observation that the calcareous $\left(\mathrm{CaCO}_{3}\right)$ cover of the cysts was only formed in the initial stages of culture growth (Olli \& Anderson 2002), it can be hypothesised that inorganic carbon was a second limiting nutrient in the tubes. Assuming a seawater inorganic carbon concentration of $2.3 \mathrm{~mol} \mathrm{~m}^{-3}$ (Stumm \& Morgan 1996), the $\mathrm{C}: \mathrm{N}$ ratios in $\mathrm{f} / 4$ and $\mathrm{f} / 2$ medium are 5.2 and 2.6 respectively. The carbon content of a vegetative Scrippsiella lachrymosa $\left(V=3591 \mu^{3}\right.$, see 'Methods') is $10^{0.94 \times \log V-0.6} / 12$ (Smayda 1978) = $46 \mathrm{pmol}$ $\mathrm{C}_{\text {cell }}{ }^{-1}$. Combined with an $\mathrm{N}$ quota of $18 \mathrm{pmol} \mathrm{cell}^{-1}$ (Eq. 2h1), the vegetative cells of $S$. lachrymosa have a $C: N=2.6$, which is exactly the $C: N$ of $f / 2$ medium. This would mean that $\mathrm{f} / 4$ medium $(\mathrm{C}: \mathrm{N}=5.2)$ contains $\mathrm{a}$ sufficient initial inorganic carbon concentration but that $\mathrm{f} / 2$ medium contains the precise initial inorganic carbon concentration to yield the amount of vegetative cells that was observed experimentally and calculated by the model (Table 2). However, the formation of larger and $\mathrm{CaCO}_{3}$-covered cysts in the early stages of the cultures (Olli \& Anderson 2002) means that relatively more inorganic carbon is needed for cyst formation than for vegetative cells alone. In $\mathrm{f} / 2$ medium this could well lead to carbon limitation of cyst production, especially if the diffusion of $\mathrm{CO}_{2}$ from the atmosphere into the culture medium is hampered, as in closed tubes (Olli et al. 2004). Culture wells in plates have a large surface:volume ratio that may sustain $\mathrm{CO}_{2}$ diffusion, increasing overall $\mathrm{C}: \mathrm{N}$ in time, leading to complete encystment even in f/2 medium (Olli \& Anderson 2002). Clearly, inorganic carbon limitation of dinoflagellates, especially those producing calcareous cysts in culture media with high $\mathrm{N}$ and $\mathrm{P}$ concentrations as $\mathrm{f} / 2$, should be considered as one of the causes for the often observed low encystment percentages in batch cultures (Anderson et al. 1984).

The model calculations (Fig. 2) depended on experimental quantification of the motile cells and the cysts of Scrippsiella lachrymosa in batch culture. Although the authors stressed that their counting statistics were poor (Olli et al. 2004), their data were sufficient to simulate motile cell and cyst development as well as the high encystment success in f/4 medium. In addition, the model permitted the calculation of meaningful S. lachrymosa vegetative cell growth and encystment rates. The model should be tested with other species of dinoflagellates and must be extended if temporary cysts, or hypnospores, are part of the life cycle (van den Hoek et al. 1995, Garces et al. 1998) or when the duration of the planozygote stage is too long to be neglected.

In contrast to batch cultures, net cell growth rates as well as encystment rates in the sea cannot be measured accurately from counts due to dispersion, sedimentation and natural losses such as grazing. The measurement of gross in situ growth rates by measuring the fraction, not the cell concentrations, of the population undergoing mitosis gets around such complications (McDuff \& Chisholm 1982, Carpenter \& Chang 1988, Chang \& Carpenter 1988, 1990, 1991, Antia et al. 1990). If the stages of the sexual cycle can be identified properly, the cohort of encysting planozygotes could possibly be used as a means of measuring the in situ encystment rate of a dinoflagellate. However, this encystment rate should not be considered as a direct loss factor of the growth rate (Olli et al. 2004) but as a loss factor of the vegetative cell population. Furthermore, encystment probability is the chance that a planozygote will transform into a cyst and is dependant on the probability of 2 gametes fusing to form a 
planozygote, which is a function of their size, swimming speed and concentration (Peperzak unpubl.). Encystment success or encystment yield should not be calculated from rates but from the cumulative fraction of the population of dinoflagellates that, in the course of days to months, has formed cysts. Encystment success will therefore remain a difficult variable to measure in situ.

Acknowledgements. Thanks to Dr. K. Olli (University of Tartu, Estonia), who enthusiastically discussed his Scrippsiella lachrymosa experiments. Dr. M. Montresor and Prof. G. M. Hallegraeff gave valuable comments on the manuscript. The manuscript also benefited from the comments of 3 anonymous reviewers.

\section{LITERATURE CITED}

Anderson DM, Kulis DM, Binder BJ (1984) Sexuality and cyst formation in the dinoflagellate Gonyaulax tamarensis: cyst yield in batch cultures. J Phycol 20:418-425

Antia AN, Carpenter EJ, Chang J (1990) Species-specific phytoplankton growth rates via diel DNA synthesis cycles. III. Accuracy of growth rate measurement in the dinoflagellate Prorocentrum minimum. Mar Ecol Prog Ser 63: 273-279

Blackburn SI, Hallegraeff GM, Bolch CJ (1989) Vegetative reproduction and sexual life cycle of the toxic dinoflagellate Gymnodinium catenatum from Tasmania, Australia. J Phycol 25:577-590

Carpenter EJ, Chang J (1988) Species-specific phytoplankton growth rates via diel DNA synthesis cycles. I. Concept of the method. Mar Ecol Prog Ser 43:105-111

Cetta CM, Anderson DM (1990) Cell cycle studies of the dinoflagellates Gonyaulax polyedra Stein and Gyrodinium uncatenum Hulburt during asexual reproduction. J Exp Mar Biol Ecol 135:69-84

Chang J, Carpenter EJ (1988) Species-specific phytoplankton growth rates via diel DNA synthesis cycles. II. DNA quantification and model verification in the dinoflagellate Heterocapsa triquetra. Mar Ecol Prog Ser 44:287-296

Chang J, Carpenter EJ (1990) Species-specific phytoplankton growth rates via diel DNA synthesis cycles. IV. Evaluation of the magnitude of error with computer-simulated cell populations. Mar Ecol Prog Ser 65:293-304

Chang J, Carpenter EJ (1991) Species-specific phytoplankton growth rates via diel DNA synthesis cycles. V. Application to natural populations in Long Island Sound. Mar Ecol Prog Ser 78:115-122

Coats DW, Tyler MA, Anderson DA (1984) Sexual processes in the life cycle of Gyrodinium uncatenum (Dinophyceae): a morphogenetic overview. J Phycol 20:351-361

Dale B (1983) Dinoflagellate resting cysts: 'benthic plankton'. In: Fryxell GA (ed) Survival strategies of the algae. Cambridge University Press, Cambridge, UK, p 69-136

Elbrächter M (2003) Dinophyte reproduction: progress and conflicts. J Phycol 39:629-632

Figueroa RI, Bravo I (2005) A study of the sexual reproduction and determination of mating type of Gymnodinium nolleri (Dinophyceae) in culture. J Phycol 41:74-83

Gao X, Dodge JD, Lewis J (1989) Gamete mating and fusion in the marine dinoflagellate Scrippsiella sp. Phycologia 28: $342-351$

Editorial responsibility: Otto Kinne (Editor-in-Chief), Oldendorf/Luhe, Germany
Garces E, Delgado M, Maso M, Camp J (1998) Life history and in situ growth rates of Alexandrium taylori (Dinophyceae, Pyrrophyta). J Phycol 34:880-887

Garces E, Zingone A, Montresor M, Reguera B, Dale B (eds) (2002) LIFEHAB: Life histories of microalgal species causing harmful blooms. Office for the Official Publications of the European Communities, Luxembourg

Giacobbe MG, Yang X (1999) The life history of Alexandrium taylori (Dinophyceae). J Phycol 35:331-338

Lewis J (2002) Data on encystment and excystment rates in dinoflagellates. In: Garces E, Zingone A, Montresor M, Reguera B, Dale B (eds) LIFEHAB: Life histories of microalgal species causing harmful blooms. Office for the Official Publications of the European Communities, Luxembourg, p 49-52

McDuff RE, Chisholm SW (1982) The calculation of in situ growth rates ofphytoplankton populations from fractions of cells undergoing mitosis: a clarification. Limnol Oceanogr 27:783-788

Olli K (2002) High encystment of a dinoflagellate in batch culture. In: Garces E, Zingone A, Montresor M, Reguera B, Dale B (eds) LIFEHAB: Life histories of microalgal species causing harmful blooms. Office for the Official Publications of the European Communities, Luxembourg, p 53-56

Olli K, Anderson DM (2002) High encystment success of the dinoflagellate Scrippsiella cf. lachrymosa in culture experiments. J Phycol 38:145-156

Olli K, Neubert MG, Anderson DM (2004) Encystment probability and encystment rate: new terms to quantitatively describe formation of resting cysts in planktonic microbial populations. Mar Ecol Prog Ser 273:43-48

Peperzak L, Colijn F, Vrieling EG, Gieskes WWC, Peeters $\mathrm{JCH}$ (2000) Observations of flagellates and stars in colonies of Phaeocystis globosa (Prymnesiophyceae); a hypothesis for their position in the life cycle. J Plankton Res 22:2181-2203

Pfiester LA (1975) Sexual reproduction of Peridinium cinctum f. ovoplanum (Dinophyceae). J Phycol 11:259-265

Pfiester LA, Anderson DM (1987) Dinoflagellate reproduction. In: Taylor FJR (ed) The biology of dinoflagellates. Blackwell, Oxford, UK, p 611-648

Pollingher U (1988) Freshwater armored dinoflagellates: growth, reproduction strategies, and population dynamics. In: Sangren CD (ed) Growth and reproductive strategies of freshwater phytoplankton. Cambridge University Press, Cambridge, UK, p 134-174

Sgrosso S, Esposito F, Montresor M (2001) Temperature and daylength regulate encystment in calcareous cyst-forming dinoflagellates. Mar Ecol Prog Ser 211:77-87

Smayda TJ (1978) From phytoplankton to biomass. In: Sournia A (ed) Phytoplankton manual, Vol 6. UNESCO, Paris, p 273-279

Stumm W, Morgan JJ (1996) Aquatic chemistry, chemical equilibria and rates in natural waters. Wiley, New York

Tomas CR, Montresor M, Tosti E (1989) Nutrient and temperature effects on growth and sexual phases of four marine dinoflagellates. In: Okaichi T, Anderson DM, Nemoto T (eds) Red tides: biology, environmental science, and toxicology. Elsevier, Amsterdam

van den Hoek C, Mann DG, Jahns HM (1995) Algae. An introduction to phycology, Cambridge University Press, Cambridge, UK

von Stosch HA (1973) Observations on vegetative reproduction and sexual life cycles of two freshwater dinoflagellates, Gymnodinium pseudopalustre Schiller and Woloszynskia apiculata sp. nov. Br Phycol J 8:105-134 